Publiser
Graduate Program Universitas Galuh
Master of Manajemen Studies Program
O22017

\title{
PENGARUH KEPEMIMPINAN DAN KEPUASAN KERJA TERHADAP MOTIVASI KERJA KARYAWAN: STUDI PADA BANK BJB CABANG CIAMIS
}

\author{
Anggun Parassuci Adely
}

\author{
Master of Management Studies Program, Graduate Program Universitas Galuh Ciamis \\ e-mail :parassuci@gmail.com
}

\author{
Article History : \\ Recieved 12 April 2017 \\ Recieved in revished form \\ 21 April 2017 \\ Acepted 5 May 2017 \\ Available offline 10 May 2017 \\ Available online 10 May 2017
}

Language Transcript :

Indonesia

Key Words :

Kepemimpinan

Kepuasan Kerja

Motivasi Kerja

\section{PENDAHULUAN}

Untuk mencapai hasil yang optimal, perusahaan membutuhkan sebuah sistem yang mampu bekerja secara sinergi dan dinamis. Sistem ini melibatkan sumber daya manusia yang efisien, teknologi yang mengikuti perkembangan zaman, dan kebijakan-kebijakan perusahaan yang dapat mendukung interaksi antara sumber daya manusia dan teknologi. Teknologi yang digunakan, yang paling penting dalam proses penyatuan faktor-faktor yang dimiliki oleh perusahaan dalam rangka proses pencapaian tujuannya yaitu Sumberdaya Manusia. Faktor inilah yang menggerakkan seluruh faktor-faktor yang
Abstract - Artikel ini diarahkan untuk melihat pengaruh kepemimpinan terhadap motivasi kerja karyawan pada Bank BJB Cabang Ciamis, pengaruh kepuasan kerja terhadap motivasi kerja karyawan dan pengaruh kepemimpinan dan kepuasan kerja terhadap motivasi kerja karyawan pada Bank BJB Cabang Ciamis. Metode yang dilakukan adalah metode deskriptif kuantitatif. Adapun hasil penelitian yang diperoleh Cabang Ciamis termasuk pada kategori baik, dengan motivasi kerja karyawan termasuk kategori tinggi. Jika kepemimpinan pada Bank BJB Cabang Ciamis ditingkatkan, maka motivasi kerja karyawan akan lebih meningkat. Disisi lain kepuasan kerja termasuk pada kategori tinggi, begitu juga dengan motivasi kerja karyawan termasuk kategori tinggi. Apabila kepuasan kerja ditingkatkan, maka motivasi kerja karyawan akan lebih meningkat. Berdasarkan hasil penelitian kepemimpinan pada Bank BJB Cabang Ciamis dan kepuasan kerja termasuk pada kategori tinggi, motivasi kerja karyawan termasuk kategori tinggi. Rekomendasi atas keilmuan manajemen jika kepemimpinan pada Bank BJB Cabang Ciamis dan kepuasan kerja ditingkatkan, maka motivasi kerja karyawan akan lebih meningkat. sudah dimiliki perusahaan dalam rangka proses pencapaian tujuan perusahaan.

Namun dalam prakteknya, orang bekerja dan melakukan tugas serta bertanggung jawab pada pekerjaannya, sering dipengaruhi oleh gaya kepemimpinan dari manajer, perusahaan atau organisasi tersebut (Iskandar, 2005). Dengan kemampuan yang dimiliki oleh pimpinan, dapat mempengaruhi karyawannya melakukan pekerjaan sesuai dengan apa yang diarahkan dan diinginkannya dalam mencapai tujuan organisasi. Untuk mencapai tujuan itu, maka peranan pemimpin untuk menciptakan motivasi kerja karyawan yang tinggi yang 
merupakan sesuatu yang dibutuhkan oleh organisasi tersebut.

Mengingat motivasi kerja mempengaruhi tindakan seorang karyawan, maka apabila suatu perusahaan tersebut akan memperoleh hasil yang lebih menguntungkan sehingga terjadi peningkatan produktivitas. Sebaliknya apabila suatu perusahaan mempunyai karyawan yang motivasi kerjanya rendah dalam melakukan pekerjaan, sudah barang tentu perusahaan atau organisasi tersebut akan mengalami kerugian karena karyawannya bekerja tidak produktif dan dapat dikatakan sebagai penurunan kinerja.

Penerapan kepemimpinan sangatlah berpengaruh terhadap motivasi kerja karyawan, karena di dalam motivasi kerja karyawan untuk memenuhi kebutuhannya sangat membutuhkan dukungan dari seorang pimpinan, karena itu setiap pemimpin harus mengetahui secara jelas tentang apa yang dibutuhkan oleh karyawan dan perusahaan agar mereka bisa bekerja sama secara efektif.

Masalah yang terjadi di PT Bank BJB Cabang Ciamis dimana motivasi kerja karyawan pada setiap divisinya mengalami penurunan sehingga seringkali terjadi kemandekan dalam penyelesaian pekerjaan yang di instruksikan pimpinan. Adanya pergantian pimpinan juga akan berdampak pada motivasi kerja, sehingga menimbulkan perubahan sikap perilaku kerja yang dibawa oleh pimpinan yang baru yang berdampak pula pada kinerja karyawan.

Berdasarkan permasalahan tersebut bahwa kurangnya motivasi kerja pada diri karyawan tersebut sehingga diperlukan ketegasan dari pimpinan terhadap karyawan agar karyawan mempunyai motivasi yang tinggi dan loyal terhadap perusahaan. Fenomena yang terjadi adalah adanya perbedaan pendapat tentang bagaimana gaya kepemimpinan yang baik menurut para karyawan.
Faktor lain yang mempengaruhi motivasi kerja adalah kepuasan kerja. Kepuasan kerja (job satisfaction) didefinisikan sebagai suatu perasaan positif tentang pekerjaan seseorang yang merupakan hasil dari evaluasi karakteristik-karakteristiknya (Robbins, 2008). Orang yang merasa puas menganggap kepuasan sebagai suatu rasa senang dan sejahtera karena dapat mencapai suatu tujuan atau sasaran. Setiap pimpinan perusahaan perlu mengetahui informasi mengenai kepuasan karyawannya dalam bekerja secara akurat sebagai bahan pertimbangan dalam mengambil keputusan untuk memecahkan masalah yang dihadapi dalam perusahaan. Berdasarkan uraian di atas, maka penulis tertarik untuk melakukan penelitian lebih lanjut mengenai, Pengaruh Kepemimpinan dan Kepuasan Kerja terhadap Motivasi Kerja Karyawan, Studi kasus pada Bank BJB Cabang Ciamis.

\section{METODOLOGI}

Metode penelitian yang akan digunakan dalam penyusunan tesis ini adalah deskriptif dan verifikatif. Penelitian deskriptif adalah suatu metode yang menggambarkan apa yang dilakukan berdasarkan fakta-fakta atau kejadian-kejadian pada objek yang diteliti, untuk kemudian diolah menjadi suatu data dan selanjutnya akan dilakukan suatu analisis sehingga pada akhirnya dihasilkan suatu kesimpulan. Sedangkan penelitian verifikatif adalah suatu metode yang dilakukan untuk menguji hipotesis dengan menggunakan perhitungan dari statistik.

Mengingat sifat penelitian ini adalah deskriftif dan verifikatif yang dilaksanakan melalui pengumpulan data di lapangan, maka metode penelitian yang digunakan adalah metode deskrtiptif survey dan explanatory survey. Tipe penyelidikan yang dilakukan adalah causalitas karena menerangkan suatu pengaruh dari satu variabel terhadap variabel lainnya.

Penelitian ini dilakukan di Bank BJB cabang Ciamis Jl. Jendral Sudirman No. 71 Ciamis, pada bulan Oktober sampai dengan bulan Mei 2016 dengan populasi jumlah 
karyawan sebanyak 94 orang. Teknik pengumpulan data dilakukan dengan menggunakan kuisioner.

Penelitian ini menggunakan desain penelitian menurut tingkat eksplanasi karena menjelaskan hubungan kausal antara variabel-variabel melalui pengujian hipotesis. Hal ini sesuai dengan pendapat Singarimbun dan Effendi (1989 : 5) bahwa: "apabila peneliti menjelaskan hubungan kausal antara variabel-variabel melalui pengujian hipotesis, maka dinamakan penelitian penjelasan atau explanatory research. Di mana menurut pendapat ahli lain yaitu (Sugiyono (2001 : 6) bahwa: "Penelitian menurut tingkat eksplanasi adalah tingkat penjelasan bagaimana variabel-variabel yang diteliti itu akan menjelaskan objek yang diteliti melalui data yang terkumpul").

\section{HASIL DAN PEMBAHASAN}

\subsection{Pengaruh Kepemimpinan Terhadap Motivasi Kerja}

Berdasarkan hasil analisis data diketahui bahwa pengaruh variabel kepemimpinan terhadap motivasi kerja sebesar 16,89\%, dengan demikian variabel kepemimpinan berpengaruh positif dan signifikan terhadap motivasi kerja. Artinya jika kepemimpinan meningkat, maka motivasi kerja juga akan meningkat.

Berdasarkan hasil analisis data, diketahui bahwa terdapat pengaruh positif dan signifikan kepemimpinan terhadap motivasi kerja karyawan Bank BJB Cabang Ciamis. Artinya jika terjadi kenaikan kepemimpinan, maka akan diikuti oleh kenaikan motivasi kerja karyawan Bank BJB Cabang Ciamis. Dengan kepemimpinan yang baik, maka motivasi kerja karyawan Bank BJB Cabang Ciamis akan lebih tinggi.

Kepemimpinan yang baik adalah yang mampu memprakarsai struktur, menjaga koordinasi dan integritas organisasi, merumuskan tujuan organisasi, menentukan sarana serta cara - cara yang efisien, menengahi pertentangan dan konflikkonflik yang muncul, mengadakan evaluasi, mengadakan revisi perubahan, inovasi pengembangan, dan melakukan penyempurnaan dalam organisasi.

Hasil di atas sejalan dengan pendapat Yamin dan Maisah (2010: 74) mengemukakan bahwa kepemimpinan adalah suatu proses mempengaruhi yang dilakukan oleh seseorang dalam mengelola anggota kelompoknya untuk mencapai tujuan organisasi. Kepemimpinan merupakan bentuk strategi atau teori memimpin yang tentunya dilakukan oleh orang yang biasa kita sebut sebagai pemimpin. Pemimpin adalah seseorang dengan wewenang kepemimpinannya mengarahkan bawahannya untuk mengerjakan sebagian dari pekerjaannya dalam mencapai tujuan.

Pemimpin adalah mereka yang menggunakan wewenang formal untuk mengorganisasikan, mengarahkan, mengontrol para bawahan yang bertanggung jawab, supaya semua bagian pekerjaan dikoordinasi demi mencapai tujuan perusahaan. Pemimpin pertama-tama harus seorang yang mampu menumbuhkan dan mengembangkan segala yang terbaik dalam diri para bawahannya. Secara sederhana pemimpin yang baik adalah seorang yang membantu mengembangkan orang lain, sehingga akhirnya mereka tidak lagi memerlukan pemimpinnya itu.

Menurut Kartono (2003: 48) mengemukakan kepemimpinan sebagai berikut, kepemimpinan itu sifatnya spesifik, khas, diperlukan bagi situasi khusus. Sebab dalam satu kelompok yang melakukan aktivitasaktivitas tertentu, dan punya tujuan serta peralatan khusus, pemimpin kelompok dengan ciri- ciri karakteristiknya itu merupakan fungsi dari situasi khusus tadi. Jelasnya sifat-sifat utama dari pemimpin dan kepemimpinannya harus sesuai dan bisa diterima oleh kelompoknya, juga 
bersangkutan, serta cocok-pas dengan situasi dan zamannya.

Fungsi pemimpin dalam organisasi yaitu meprakarsai struktur, menjaga koordinasi dan integritas organisasi, merumuskan tujuan organisasi, menentukan sarana serta cara - cara yang efisien, menengahi pertentangan dan konflik-konflik yang muncul, mengadakan evaluasi, mengadakan revisi, perubahan, inovasi pengembangan, serta melakukan penyempurnaan dalam organisasi. Dari uraian tersebut kepemimpinan Bank BJB Cabang Ciamis harus terus diinternalisasikan oleh semua karyawan dan di evaluasi secara berkelanjutan oleh management guna menjaga tingkat motivasi kerja karyawan.

\subsection{Pengaruh Kepuasan kerja Terhadap Motivasi Kerja}

Berdasarkan hasil analisis data diketahui bahwa pengaruh variabel kepuasan kerja terhadap motivasi kerja sebesar 23,43\%, dengan demikian variabel kepuasan kerja berpengaruh positif dan signifikan terhadap motivasi kerja. Artinya jika kepuasan kerja meningkat maka motivasi kerja juga akan mengalami peningkatan.

Berdasarkan hasil analisis data, diketahui bahwa terdapat pengaruh positif dan signifikan kepuasan kerja terhadap motivasi kerja karyawan Bank BJB Cabang Ciamis. Artinya jika terjadi kenaikan pada kepuasan kerja, maka akan diikuti oleh kenaikan motivasi kerja karyawan Bank BJB Cabang Ciamis. Dengan kepuasan kerja yang tinggi, maka motivasi kerja karyawan Bank BJB Cabang Ciamis akan lebih tinggi.

Dimana kepuasan kerja yang dirasakan oleh karyawan pada umumnya tercermin dalam sikap positif karyawan terhadap pekerjaan dan segala sesuatu yang dihadapi ataupun yang ditugaskan kepadanya di lingkungan kerja. Sebaliknya apabila Kepuasan kerja tidak tercapai maka dapat berakibat buruk terhadap perusahaan. Akibat buruk itu berupa kemalasan, kemangkiran, mogok http://jurnal.unigal.ac.id/index.php/managementreview

kerja, pergantian tenaga kerja dan akibat buruk yang merugikan lainnya.

Menurut Reksohadiprodjo dan Handoko (2000: 56) mengemukakan bahwa: "Kepuasan kerja adalah keadaan emosional yang menyenangkan atau tidak menyenangkan dengan mana para karyawan memandang pekerjaan mereka. Kepuasan kerja mencerminkan perasaan seseorang terhadap pekerjaannya".

Hackman and Lawler (dalam Hackman and Oldham, 1975: 159-170) mengungkapkan bahwa, kepuasan kerja akan tercapai jika ada kesuaian antara keinginan dari para pekerja dan dimensi inti pekerja (Five core job dimensions) yang terdiri dari skill variety, task significance, task identity, autonomy and feed back".

Sedangkan menurut Handoko (2008:24) bahwa, kepuasan kerja adalah keadaan emosional yang menyenangkan dengan mana para karyawan memandang pekerjaan mereka. Kepuasan kerja mencerminkan perasaan seseorang terhadap pekerjaannya. Ini dampak dalam sikap positif karyawan terhadap pekerjaan dan segala sesuatu yang dihadapi di lingkungan kerjanya.

Menurut beberapa definisi tentang kepuasan kerja diatas, dapat disimpulkan bahwa kepuasan kerja adalah suatu perbandingan antara persepsi dan harapan seseorang yang dalam hal ini berupa imbalan yang diterima dari pekerjaan yang dilakukan dengan harapan karyawan karyawati dari pekerjaan yang dilaksanakan.

Melihat pentingnya kepuasan kerja seperti tersebut, maka Bank BJB Cabang Ciamis perlu menyediakan program reward dan punishment. Perencanaan kepuasan kerja dalam sebuah organisasi memang tanggung jawab dari organisasi. Namun demikian, masing-masing individu juga perlu melakukan perencanaan kepuasan kerja, melalui pengembangan diri masing-masing individu. 


\subsection{Pengaruh Kepemimpinan dan Kepuasan kerja Terhadap Motivasi Kerja}

Berdasarkan hasil analisis data, diperoleh korelasi variabel kepemimpinan dan kepuasan kerja terhadap motivasi kerja sebesar 0.843 pada tingkat signifikansi 0.000. Sedangkan nilai koefisien determinasi (KD) atau $\mathrm{R}^{2}(R$ Square $)$ sebesar 0.711, hal ini menunjukkan bahwa besarnya pengaruh kepemimpinan dan kepuasan kerja terhadap kepuasan kerja sebesar $71,1 \%$. Dengan demikian variabel kepemimpinan dan kepuasan kerja berpengaruh positif dan signifikan terhadap motivasi kerja. Artinya jika terjadi kenaikan kepemimpinan dan kepuasan kerja, maka akan diikuti oleh kenaikan motivasi kerja karyawan Bank BJB Cabang Ciamis.

Berdasarkan hasil analisis data, diketahui bahwa terdapat pengaruh positif dan signifikan pada kepemimpinan dan kepuasan kerja terhadap motivasi kerja karyawan Bank BJB Cabang Ciamis. Artinya jika terjadi kenaikan kepemimpinan dan kepuasan kerja, maka akan diikuti oleh kenaikan motivasi kerja karyawan Bank BJB Cabang Ciamis. Dengan kepemimpinan dan kepuasan kerja yang tinggi, maka kepuasan kerja karyawan Bank BJB Cabang Ciamis akan lebih tinggi.

Menurut Saydam (2005:370) ada beberapa faktor yang dapat mempengaruhi motivasi diantaranya faktor intern dan faktor ekstern.

1. Faktor intern yang mempengaruhi pemberian motivasi pada seseorang antara lain:
a. Kematangan pribadi
b. Tingkat pendidikan
c. Keinginan dan harapan pribadi
d. Kebutuhan
e. Kelelahan dan kebosanan
f. Kepuasan kerja

2. Faktor ekstern yang mempengaruhi motivasi dapat mencakup:
a. Lingkungan/kondisi kerja yang menyenangkan
b. Kompensasi yang memadai
c. Supervise yang baik
d. Adanya penghargaan atas prestasi
e. Status dan tanggung jawab
f. Peraturan yang berlaku

Sedangkan menurut Rivai (2009:456) ada beberapa aspek yang berpengaruh terhadap motivasi kerja karyawan yakni:

1. Rasa aman dalam bekerja

2. Mendapatkan gaji yang adil dan kompetitif

3. Lingkungan/kondisi kerja yang menyenangkan

4. Penghargaan atas prestasi kerja, dan

5. Perlakuan yang adil dari manajemen.

Berdasarkan beberapa pendapat para ahli di atas dapat disimpulkan bahwa faktor-faktor yang dapat mempengaruhi motivasi kerja karyawan salah satunya adalah lingkungan kerja yang kondusif dan menyenangkan. Pihak perusahaan harus selalu memperhatikan karyawannya agar dapat bekerja lebih optimal, karena pada dasarnya karyawan merupakan suatu hal yang tidak dapat dipisahkan dari perusahaan.

Untuk menjaga motivasi karyawan agar tetap baik adalah dengan selalu memperhatikan faktor-faktor apa saja yang dapat mempengaruhi karyawan agar tetap bersemangat dan bergairah dalam bekerja. Karena motivasi kerja dipengaruhi oleh kepemimpinan dan kepuasan kerja, Bank BJB Cabang Ciamis harus terus konsisten melakukan evaluasi dan peningkatan terhadap variabel tersebut guna menjaga stabilitas motivasi kerja karyawan. 


\section{SIMPULAN}

Berdasarkan hasil penelitian dan pembahasan, maka penulis menarik kesimpulan hasil penelitian bahwa Kepemimpinan pada Bank BJB cabang Ciamis cenderung tinggi demikian juga motivasi kerja karyawan cenderung tinggi. Dengan demikian kepemimpinan berpengaruh positif terhadap motivasi kerja karyawan. Kepuasan kerja pada Bank BJB cabang Ciamis cenderung tinggi demikian juga motivasi kerja karyawan cenderung tinggi. Dengan demikian kepuasan kerja berpengaruh positif terhadap motivasi kerja karyawan. Kepemimpinan dan kepuasan kerja pada Bank BJB cabang Ciamis cenderung tinggi demikian juga motivasi kerja karyawan cenderung tinggi. Dengan demikian kepemimpinan dan kepuasan kerja berpengaruh positif terhadap motivasi kerja karyawan.

\section{DAFTAR PUSTAKA}

Anoraga, 2011. Motivasi Kerja. [Online] tersedia di https://nanashevo.wordpress.com/ motivasi- kerja/.[21 Januari 2016]

As'ad, M. 2003. Seri Ilmu Sumber Daya Manusia: Psikologi Industri. Yogyakarta: Liberti Yogyakarta.

Danim, Sudarwan. 2004. Kinerja Staf dan Organisasi. Bandung: Pustaka Setia.

Darmawati, dkk. 2006Pengaruh Kepuasan Kerja dan Kepemimpinan terhadap Motivasi Kerja (Studi pada Karyawan Fakultas Ilmu Sosial dan Ekonomi Universitas Negeri Yogyakarta). [Online] Yogyakarta: UNY.

Eflina dkk 2004Pengaruh Kepemimpinan dan Kepuasan Kerja terhadap Motivasi Kerja. [Jurnal] Bandung: Program Pascasarjana UPI Bandung.

Gibson, Ivancevich, dan Donnely, 1991. Organiations, Bussines. Texas: Pulication, Inc.

Gomes, Faustino C. 2000. ManajemenSumberDayaManusia. Andi Offset: Yogyakarta

Hackman and Oldham, 1975.Employee Creativity : Personal andContextual Factor at Work", Academy of Management Journal, Vol. 39 ,pp. 607-634
Martoyo,

$\mathrm{S}$. 2000. ManajemenSumberDayaManusia. Yogjakarta: BPFE.

Riggio, Ronald E. 2000. Introduction to Industrial/Organizational Psychology, Third Edition, Printice Hall, Upper Saddle River, New Jersey 07458.

Sugiyono, 2013. Statistika Untuk Penelitian, Jakarta: Alfabeta.

Surakhmad, Winarno 1994. Pengantar Penelitian Ilmiah. Bandung: Tarsito

Suyanto, dkk 2001. Refleksi dan Reformasi Pendidikan Indonesia Memasuki Millenium III. Yogyakarta : Adi Cita.

Thoha,Miftah.2010. Dimensi-Dimensi Prima Ilmu Administrasi Negara. Jakarta: Raja Grafindo Persada.

Uno, Hamzah.B.2007. Teori Motivasi dan Pengukurannya. Analisis di Bidang Pendidikan. Jakarta: Bumi Aksara

Wahjosumidjo, Soemaryo, 2005.Pembentukan Organisasi Melalui Motivasi dan Kerjasama. Semarang : CV. Andika Sejahtera

Waluyo, Agung, Dwi.2012. Pengaruh Kepemimpinan, Kepuasan Kerja dan Motivasi Kerja terhadap Kinerja Karyawan padaTerminal PetiKemas Semarang TPKSPelabuhan Indonesia III Tanjungmas Semarang. [Jurnal] Semarang: UNNES 